\section{South African student protests, 2015 2016: The aftermath viewed through Medical Science Honours students at the University of Cape Town}

To the Editor: The student protests of 2015 - 2016, under the banner \#FeesMustFall, swept across South Africa (SA) like a veldt fire. ${ }^{[1]}$ Several new initiatives have now become possible, thanks to the energy, vision and leadership of the students. For example, at the University of Cape Town (UCT), an agreement was reached between the university Executive and protesting students to, among other things, establish an Institutional Reconciliation and Truth Commission (IRTC). At national level, the SA government launched the Fees Commission, which is yet to finalise its work. Several students were detained, some without trial, for at least 4 months. Most affected universities failed to complete their programmes, with the UCT Faculty of Health Sciences opting for a 'mini-semester' in January 2017 to facilitate the completion of academic work remaining from the year 2016. ${ }^{[1]}$ Other universities proceeded with examinations in guarded venues during the final days of the protests, while still others seem to have used marks students had achieved up to the beginning of the protests as the final marks reflected on certificates. ${ }^{[1]}$

Now, only 6 - 18 months later, some academic effects of the 2015 - 2016 student protests are already manifesting. Reflecting on the UCT Honours in human genetics programme, we have a microcosm of students who have come through different universities and been affected differently. Our rigorous selection process for the honours programme depends on academic achievement; therefore, the different decisions taken by universities in completing their programmes are now manifesting in class.

We acknowledge that student protest action brought a new impetus to examining issues affecting higher education and education in general. But we retrospectively question the usefulness of some of the results of examinations written soon after the protests, as students were exhausted, stressed and had not completed some of their course content. On reflection, all the students we recruited this year had 'very good marks', but, practically, we are faced with students finding it more difficult than previous cohorts of recruited students to cope with the same honours course. There are many possible reasons for this, but there are several clues to support the idea that some students may not have completed their courses, as their universities opted to use available coursework marks as final results. Preliminary assessment results in our programme have seen one student deregister, and as many as $20 \%$ struggling and needing assistance to avoid a high likelihood of failure, contrasting with a history of a $100 \%$ pass rate for the past 10 years. It is possible that the issues we are facing in UCT's human genetics honours programme are shared by other disciplines across many universities nationwide. This reflection should by no means be used to stigmatise the protests by students, whose grievances are legitimate and are supported by ourselves and especially by many faculty members. The \#FeesMustFall movement has made compelling arguments regarding the need for renewed energy to transform education. ${ }^{[2,3]}$ This reflection paper is intended as a call for proactive measures from all stakeholders in education to address present and future challenges in a way that minimises negative effects on students' academic performances. It cannot be that every time we need to confront or redress vestiges of apartheid or socioeconomic ills, we wait for students to put their lives and careers on the line, similarly to the students and youths of $1976 .{ }^{[4]}$ As a society, it is important that issues raised by our students receive our full attention and that we create clear, transparent roadmaps on remedial action.

\section{Dandara, E R Chimusa, A Wonkam}

Division of Human Genetics, Department of Pathology, Faculty of Health Sciences, University of Cape Town, South Africa, and Institute of Infectious Disease and

Molecular Medicine, University of Cape Town, South Africa

collet.dandara@uct.ac.za

1. Davids N. On extending the truncated parameters of transformation in higher education in Sout Africa into a language of democratic engagement and justice. Transform Higher Edu 2016;1(1):7. https://doi.org/10.4102/the vlil. 7

2. Heleta S. Decolonisation of higher education: Dismantling epistemic violence and Eurocentrism in South Africa. Transform Higher Edu 2016;1(1):8. https://doi.org/10.4102/the.vli1.9

3. Du Preez P, Simmonds S, Verhoef AH. Rethinking and researching transformation in higher Du Preez P, Simmonds S, Verhoef AH. Rethinking and researching transformation in higher education: A meta-study of South African trends. Transform Higher Edu 2016;1(1):7. https://do

Bunting I. The higher education landscape under apartheid. In: Cloete N, Maassen P, Fehnel R, Moja T Perold H, Gibbon T (eds.). Transformation in Higher Education: Global Pressures and Local Realities in South Africa. Dordrecht: Kluwer Academic Publishers, 2004:35-52. https://doi.org/10.1007/1-40204006-7_3

S Afr Med J 2017;107(9):723. DOI:10.7196/SAMJ.2017.v107i9.12714 